\title{
INTERAKSI ISLAM DENGAN BUDAYA BARASANDI DAN AKTIVITAS SOSIAL KEAGAMAAN ORANG TOLAKI DI SULAWESI TENGGARA
}

\author{
Basrin Melam6a \\ Staf Pengajar Univ. Haluoleo Kendari. Telp. 081229452311 \\ email: melambabasrin@yahoo.com.
}

\begin{abstract}
This research aimed to describe the interaction between Islam and Tolaki tradition in South East Sulawesi. The interaction between Tolaki and Islam has two formulations, the first, Islam contaminated, changed and reformed local culture, Tolaki. This kind of formulation produced the reality of religious social life like barasandi (bersanji/aqiqah), a marriage procession (mowindahako), a celebration of circumcision (maggilo), a celebration such a praying for being saved from any problem of life, a celebration of Prophet of Muhammad birth (maulu Nabi), religious activities, an art and literature like kinoho agama (religious poems), Taenango langgai saranani (the history of heroic in Islamic spreading or proselytization in Tolaki region), religious social life like how someone performed or pilgrimaged to Mecca (hadi kobaraka), and the dynamics of social organization life. The second, Islam was contaminated by several local traditions. This case produced the process of Islam localizing in the the dynamics of Tolaki religious social community. There had been an interaction form and acculturation between Islam and Tolaki culture in Southeast Sulawesi.
\end{abstract}

Penelitian ini bertujuan untuk menjelaskan interaksi atau perjumpaan antara agama Islam dengan budaya Tolaki di Sulawesi Tenggara. Interaksi Islam dengan kebudayaan Tolaki menghasilkan dua pola, pertama, Islam memberikan warna, mengubah, mengolah, dan memperbaharui budaya lokal. Pola ini memunculkan realitas kehidupan sosial keagamaan dalam bidang budaya Barasandi (aqiqah), adat perkawinan (mowindahako), upacara sunatan (manggilo), doa selamatan (mobasa-basa), peringatan maulid (maulu nabi), aktivitas keagamaan, dalam 
bidang seni dan sastra seperti kinoho agama (pantun agama), dan Taenango langgai saranani (kisah kepahlawanan dalam penyebaran agama Islam di wilayah Tolaki), serta kehidupan sosial keagamaan misalnya orientasi haji (hadi kobaraka), dan dinamika kehidupan organisasi sosial. Kedua, Islam diwarnai oleh berbagai budaya lokal. Saluran ini memunculkan proses lokalisasi unsurunsur Islam dalam dinamika sosial keagamaan orang Tolaki. Telah terjadi bentuk interaksi, dan akulturasi antara Islam dan budaya Tolaki di Sulawesi Tenggara.

Key words: Tolaki culture, cultural transformation, Islamic values, cultural communication

\section{Pendahuluan}

Pada pembahasan kali ini kami akan mengkaji pertemuan budaya lokal dengan agama Islam yang ada di Sulawesi Tenggara secara spesifik budaya Tolaki. Suku Tolaki terbagi dua yaitu: Tolaki Konawe yaitu yang mendiami bekas kerajaan Konawe sekarang Kabupaten Konawe, Konawe Selatan, Konawe Utara dan Kota Kendari, dan Tolaki Mekongga yang mendiami bekas wilayah kerajaan Mekongga sekarang Kabupaten Kolaka dan Kolaka Utara, agar mudah untuk dipahami. Perkembangan agama Islam di tanah Tolaki Konawe sejak abad ke-17 yang telah berlangsung secara evolutif telah berhasil menanamkan akidah Islamiah dan syari'ah shahihah, memunculkan cipta, rasa, dan karsa oleh pemeluk-pemeluknya. Sebelum kedatangan Islam, masyarakat telah memeluk agama yang berkembang secara evolutif pula, baik dari penduduk asli (animisme dan dinamisme). Hal yang menarik, unsur-unsur budaya yang bertentangan dengan nilai-nilai kepatutan tersingkir dengan sendirinya, sedangkan yang baik adalah yang mengandung unsur-unsur kepatutan dan kepantasan, hidup secara berdampingan. Pada aspek lain terdapat budaya Tolaki yang sejalan dengan nilai Islam yang hingga sekarang masih dilaksanakan seperti acara Barasandi (bahasa Tolaki) atau aqiqah, perkawinan (perapua), ritual kematian (mateaha), sastra Tolaki atau kinoho agama, maupun aktivitas sosial keagamaan lainnya pada orang Tolaki.

Tulisan ini juga melihat kondisi Islam di tanah Tolaki dengan menggunakan kerangka pemahaman seperti di atas, tidak saja akan menemukan keterkaitan historis dengan realitas kesejarahan Islam, tetapi juga akan menemukan satu sisi penting dari awal proses transformasi intelektual Islam yang bertolak dari nilai-nilai universalisme Islam yang dikategorikan sebagai tradisi besar dengan tata nilai dalam setting kultural dan struktural tertentu yang sudah terpola sebelumnya. 
Tulisan ini ingin mendeskripsikan sekaligus menganalisis keberadaan barasandi (bersanji atau aqiqah), dan beberapa budaya Tolaki, maupun aktivitas sosial keagamaan yang sejalan dengan nilai ajaran Islam. Tujuannya adalah untuk memberikan gambaran tentang bagaimana agama dan tradisi berjalan dan berintegrasi dalam pola kehidupan masyarakat Islam. Realitas ini menunjukkan bahwa masyarakat Tolaki memiliki konstruksi keberagaman yang khas yang menjadi dasar munculnya bentuk dan proses barasandi atau bersanji dan beberapa tradisi Tolaki yang sejalan dengan Islam. Disinilah letak pentingnya masalah ini dianalisis, agar dapat dipahami bagaimana pola pemikiran keberagaman khususnya masyarakat Tolaki. Berdasarkan latar belakang di atas, maka pokok pembahasan dalam tulisan ini adalah melihat bagaimana bentuk perpaduan atau interaksi Islam dan budaya lokal Tolaki yang ada di Sulawesi Tenggara dalam adat, upacara, maupun kehidupan sosial keagamaan.

\section{Upacara Barasandi (Aqiqah): Antara Islam dan Tradisi}

Pengaruh Islam terhadap kehidupan (pembinaan moral) bangsa Indonesia berkisar antara tiga kemungkinan. Pertama ialah ajaran Islam berpengaruh sangat kuat terhadap pola hidup masyarakat. Kedua, Islam dan budaya (moral) bangsa berimbang, sehingga merupakan perpaduan yang harmonis. Ketiga, ajaran (moral) Islam kurang berpengaruh, sehingga merupakan perpaduan yang ikut menyempurnakan moral bangsa. Ketiga kemungkinan perpaduan itu dapat terjadi di komunitas-komunitas muslim di berbagai tempat di Indonesia.

Jika ditelisik ada nilai budaya Tolaki yang sejalan dengan nilai Islam salah satunya adalah upacara Barsanji atau Barasandi. Bersanji atau dalam bahasa Tolaki disebut barasandi yaitu suatu upacara potong rambut bagi masyarakat Tolaki di Konawe dan Kolaka Provinsi Sulawesi Tenggara. Dalam hukum Islam disebut Aqiqah (mehaqeqah), kegiatan barasandi ini di dahului dengan penyembelihan hewan kurban atau hewan aqiqah berupa kambing (obee/owembe), dengan tetap mengikuti syariat Islam. Adapun jumlah hewan yang disembelih yaitu untuk anak laki-laki sebanyak 2 (dua) ekor kambing, untuk anak perempuan atau wanita sebanyak 1 (satu) ekor kambing. Namun dalam prakteknya terdapat juga praktek bersanji atau aqiqah tanpa menyembeli binatang, hanya dengan melaksanakan pembacaan kitab barsanji dan suguhan makanan. (Wawancara Lamuse, 7 Januari 2013). Dalam tradisi orang Tolaki bahwa pelaksanaan barasandi ini kadangkala yang di pentingkan adalah 
pestanya, dengan mengundang keluarga, kerabat, dan handai taulan, untuk memberikan doa pada acara bersanji.

Acara tersebut disertai dengan memberikan sumbangan berupa uang yang dibungkus dalam amplop, setiap tamu menyimpan sumbanganya di dalam guci atau tempat yang disediakan oleh yang melaksanakan acara. Dalam tradisi barasandi dibacakan doa barsanji berupa kitab yang di karang oleh Jabal Al Barsanji dan pembacaan sholawat Nabi.

Interaksi Islam dan budaya lokal Tolaki adalah sebagai upaya untuk melihat hubungan dinamis antara Islam dengan berbagai nilai dan konsep kehidupan yang dipelihara dan diwarisi serta dipandang sebagai pedoman hidup oleh masyarakat terkait. Interaksi sebagai hubungan dinamis yang terjadi antara elemen (budaya) secara teoritis dapat bergerak diantara kutub "ekstrim". Pertemuan dua budaya yang berbeda tidak semua unsur budaya yang masuk tertolak secara keseluruhan dan juga tidak dapat terintegrasi secara penuh. Di antara dua kutub tersebut dapat terjadi proses tarik menarik yang dapat mendorong terjadinya kompromitas. Yaitu interaksi, adaptasi, akomodasi dan asimilasi.

Kehidupan beragama masyarakat Tolaki, khususnya yang muslim terbagi dalam dua kelompok, yaitu kelompok yang kurang taat (mereka seperti petugas adat,masyarakat awam yang tidak memiliki dasar pengetahuan agama Islam) dan kelompok yang taat beragama. Kelompok pertama belum sepenuhnya menjalankan kewajiban agama Islam secara baik. Pola beragamanya masih bersifat tradisional. Mereka inilah yang masih mempertahankan simbol-simbol dalam setiap upacara selamatan. Jumlah kelompok ini lebih besar jika dibandingkan kelompok masyarakat yang taat. Dalam kehidupan sehari-hari mereka tetap menjunjung tinggi nilai-nilai Islam dan kebudayaan Tolaki (Tarimana, 1993: 87). Namun, keislaman mereka tidak selalu mencerminkan pemaknaan yang relevan dengan nilai normatif ajaran agama Islam. Selain itu, masyarakat Tolaki termasuk masyarakat yang masih memperhatikan pembagian struktur. Pembagian tersebut terjadi secara diam-diam dan memunculkan hubungan sosial yang kaku. Relasi sosial diletakan diatas norma-norma tertentu yang dikenal anakia (bangsawan), odisi (pemerintah), panggasara (petugas adat), dan pangga agama (imam), to'ono nggawasa (orang kaya), to'ono pindara rongga mandara (orang pintar dan memiliki keterampilan), tua ngguru (guru/Ustadz), padangga (pedagang), maupun struktur yang lainnya.

Kelompok kedua adalah kelompok masyarakat yang menunjukan peningkatan kualitas keagamaan. Hal ini menunjukan dengan kegiatan 
sehari-hari seperti aktivitas pengajian, sholat berjamaah, kegiatan tarbiyah setiap pekan, dan beberapa kegiatan yang berhubungan dengan peningkatan Thaqafiyyat. Mereka ini memiliki pengetahuan keagamaan dan menjalankan syariat Islam secara utuh dan konsekwen.

Sebagian masyarakat Tolaki mengganggap bahwa pembacaan kitab al Barsanji lebih penting, jika dibandingkan dengan syarat, rukun dan adab Aqiqah. Hal ini disebabkan oleh ketidak pahaman sebagian masyarakat Tolaki. Menurut pandangan masyarakat Tolaki bahwa bukan rukun dan syarat syahnya suatu syariat yang disebut aqiqah, tetapi pembacaan kitab bersanji. Pandangan ini dianut oleh kelompok yang kurang taat (tidak memiliki dasar pengetahuan agama Islam). Jika ditelaah bahwa sebenarnya Aqiqah harus memenuhi syarat dan rukunnya, jika dibandingkan dengan pembacaan kitab al Barsanji sebagian menganggap bahwa hal ini adalah bid'ah. Sebagian juga berpendapat bahwa barasandi atau barsanji adalah merupakan syiar Islam karena di dalam kitab Al Barsanji ini terdapat kisah-kisah atau syiroh nabawiyah yang menceritakan kehidupan Nabi Muhammad SAW, sejak sebelum dilahirkan, masa kecil, remaja, kehidupan Nabi, watak dan kebiasaan Nabi Muhammad, kisah Isra dan Mi'raj hingga diangkat menjadi Rasul. Disamping itu dalam acara barsanji dibacakan sholawat sambil berdiri bersamaan dengan memotong rambut bayi.

Fenomena ini menunjukkan bahwa fikih Islam adalah hukum yang hidup dan berkembang yang mampu bergumul dengan persoalan-persoalan lokal yang senantiasa meminta etik dan paradigma baru. Keluasan hukum Islam adalah satu bukti adanya ruang gerak dinamis itu. Ia merupakan implementasi objektif dari doktrin Islam yang meskipun berdiri di atas kebenaran mutlak dan kokoh, juga memiliki ruang gerak dinamis bagi perkembangan, pembaharuan, dan kehidupan sesuai dengan fleksibilitas ruang dan waktu.

Dalam konteks pelaksanaan barasandi lebih pada ingin menghadirkan bahwa anak mereka telah hadir ditengah keluarga dan masyarakat, juga merupakan tradisi penyambutan kelahiran seorang anak, dan juga sebagai rasa syukur kepada Allah SWT. Upacara penyembelihan binatang dilakukan oleh seorang imam (O'ima), dengan membaca doa (O'doa) menyembelih binatang. Sebelum melakukan penyembelihan binatang seorang imam terlebih dahulu melakukan hal-hal sebagai berikut: kambing terlebih dahulu di bersihkan dengan cara dimandikannya dan nidene atau berwudhu, setelah itu dirias dengan memakaikan bedak, lipstick, mencilak kelopak mata kambing, selanjutnya di berikan kuteks atau pewarna kuku, dan terakhir kambing dihadapkan pada 
cermin, selanjutnya mata kambing ditutup dengan kain putih. Setelah dirias maka kambing tersebut segera disembeli oleh imam. Tradisi ini tidak ada dalam Islam tetapi para imam di kampung tetap melaksanakan hal tersebut.

Hal diatas disebabkan oleh pertama, berkaitan dengan konsep kepercayaan kambing merupakan binatang yang di sakralkan bagi masyarakat Islam Tolaki yang merupakan binatang peliharaan Nabi Muhammad SAW, dan memiliki kedudukan di akhirat disamping itu kambing bagi masyarakat Tolaki sangat disakralkan. Kedua, binatang harus di berlakukan secara baik dengan etika penyembelihan, karena di akhirat binatang ini merupakan binatang istimewa dan akan meminta pertanggung jawaban terhadap orang yang menyembelih.

Fungsiolisme baik dari Malinowski maupun Brown dijadikan kerangka teori dalam menganalisis kebudayaan seperti barasandi sangat tepat jika dilaksanakan dengan melihat upacara sebagai sesuatu yang berfungsi bagi individu maupun masyarakat secara keseluruhan. Fungsi-fungsi tersebut berpengaruh terhadap bertahannya tradisi barsanji dikalangan Tolaki.

Pelaksanaan barasandi ini di dahului kegiatan diantaranya pada malam hari dilaksanakan acara khatam al Quran (mehatamu Qurani). Kegiatan tersebut dilengkapi dengan miniatur masjid (masigi mohewu) yang dihias, janur yang dihias dengan sederetan telur (tiolu) yang disusun rapi, ketupat nabi (kotupa nabi), nasi yang akan dibacakan doa atau kina nibasa-basa, dan lauk pauk sebagai menu makanan. Setelah selesai mepandetama Qurani seorang imam membaca doa khatam al Quran dan doa selamat.

Pada esok harinya baru dilaksanakan acara barasandi. Adapun perlengkapan upacara barasandi diantaranya beberapa sisir pisang (aso ase opundi) yang diletakan diatas tempat nampan (kapara), dan biji kelapa muda berwarna merah (kaluku momea), jumlah buah kelapa merah ini sesuai dengan jumlah bayi yang dicukur rambutnya. Kelapa tersebut dilubangi dengan pola sigsak dan airnya tetap dibiarkan ada sebagai tempat menyimpan bulu helai rambut bagi sibayi yang digunting rambutnya. Pisang melambangkan kesejukan hal ini sesuai ungkapan "morini mbuu mbundi" artinya dingin laksana pohon pisang. Tanaman pisang juga memiliki keistimewaan dapat berkembang biak (teleka) dengan cepat. Diharapkan seorang akan mengalami kesejukan dalam hidupnya dan senantiasa berkembang biak. Seusai dilaksanakan acara barasandi biasanya buah pisang tersebut digantung pada tiang tengah atau tiang raja rumah.

Buah kelapa disimbolkan umur panjang dan ketangguhan dalam menghadapi kehidupan, hal ini dianalogikan karena pohon kelapa memiliki umur yang panjang, tahan terhadap terpaan angin karena memiliki akar serabut. 
Jadi harapan akan kehidupan dan masa depan bayi tersebut dianalogikan seperti sebuah pohon pisang dan kelapa.

Teori yang dipergunakan untuk menganalisis upacara barasandi ini adalah teori fungsionalisme. Teori ini berangkat dari pemikiran positivisme dengan menekankan konsep masyarakat sebagai orgasme. Asumsi yang menjadi cirinya adalah bahwa realitas dipandang sebagai suatu sistem. Proses suatu sistem hanya dapat dipahami dalam kerangka hubungan timbal balik antara bagian-bagiannya. Disamping itu suatu sistem terikat pada proses tertentu yang bertujuan untuk memprtahankan integritas dan batas-batasnya (Soekanto, 1986: 4).

Menurut Malinowski sebagaimana dikutip Soekanto dan Lestarini, teori ini memandang bahwa semua unsur kebudayaan dianggap dapat memenuhi berbagai taraf kebutuhan biologis, psikologis, dan sosial budaya (Soekanto, 1988: 29). Setiap pola kelakuan yang sudah menjadi pola kebiasaan, setiap kepercayaan dan sikap yang merupakan bagian dari kebudayaan dalam suatu masyarakat, memenuhi beberapa fungsi mendasar dalam kehidupan masyarakat yang bersangkutan (TO, 1990: 59). Radcliffe Brown menamakan teori ini dengan strukturialisme. Konsepsinya tentang organisme masyarakat adalah bahwa fungsi yang diterapkan terhadap masyarakat manusia didasarkan pada analogi antara kehidupan sosial dengan kehidupan organis (Soekanto, 1988: 25). Berbagai aspek kehidupan sosial bukanlah berkembang untuk memuaskan kebutuhan individual, tetapi justru timbul untuk mempertahankan struktur sosial masyarakat. Nilai budaya yang terkandung dalam pelaksanaan upacara barandi selain sebagai upacara keagamaan dalam pelaksanaan syariat Islam, didalamnya barasandi ada pergeseran orientasi seperti nilai ekonomis dengan mengumpulkan sumbangan, disamping itu berorientasi pada demonstrasi status sosial, sebab yang biasa melaksanakan upacara Barsanji secara besarbesar dianggap mampu, apalagi dengan pesta yang begitu besar. Diakui dalam upacara barsanji terdapat nilai budaya yang sejalan dengan Islam, meskipun diakui terdapat tradisi setempat. Sebagian para penganut Islam ditanah Tolaki menggangap hal ini masih dalam batas kewajaran sebagai bentuk melakukan dakwah cultural yaitu berdakwah di tengah kultur dan tradisi.

\section{Budaya Perkawinan (Mepakawi) dan Kematian (Mateaha) dan Nilai Islam}

Titik temu Islam dan budaya lokal khususnya pada masyarakat Tolaki tampaknya terimplementasi dalam proses perkawinan. Kondisi ini memperlihatkan bahwa Islam, berbeda dengan pandangan sebagian kaum muslim, sangat fleksibel dengan budaya 
lokal di mana Islam memanifestasikan dirinya. Secara khusus masuknya Islam di tanah Tolaki sejak abad ke-16 telah memberi perubahan, misalnya peranan raja Lakidende dalam upayanya untuk mengembangkan agama Islam di Kerajaan Konawe sehingga pengaruhnya dapat dinikmati hingga saat ini. Setelah agama Islam secara resmi diterima oleh masyarakat Konawe, maka atas keinginan raja Lakidende mulai saat itu diumumkan kepada rakyat Konawe supaya:

1. Menghentikan untuk makan babi.

2. Menguburkan mayat menurut Islam.

3. Mendirikan Masjid di setiap kampung

4. Belajar membaca al Quran

5. Bersunat bagi laki-laki yang telah akil balig

6. Mengucapkan dua kalimat syahadat

7. Khatam al Quran

8. Pembacaan akad nikah pada saat nikah.

9. Melaksanakan aqiqah atau barasandi

Selain itu, kepada masyarakatnya dihimbau agar meninggalkan kebiasaan-kebiasaa seperti minum minuman keras (Pongasi), kawin lebih dari ketentuan ajaran Islam, dan menghentikan penyembahan kepada dewa-dewa atau Sangia. Ajaran menitik beratkan pada tauhid yaitu mengesakan Allah SWT (Melamba, 2012: 212).

Relasi harmonis antara ajaran Islam dengan budaya Tolaki khususnya dalam prosesi perkawinan adat Tolaki. Proses inkulturasi ini tampak, misalnya, di dalam prosesi perkawinan di mana unsur Islam seperti P3NTCR, pihak Kepala Urusan Agama (KUA), dan unsur adatseperti Pu'u tobu dan pabitara (juru bicara pihak laki-laki), Tolea (juru bicara pihak perempuan), bertemu dalam perhelatan tersebut. Hubungan Islam dan adat Tolaki yang tampak pada upacara perkawinan adat memperlihatkan sebuah bentuk penyesuaian, saling belajar, dan saling berdialog satu sama lain. Artinya, pada prosesi perkawinan ini tidak ada kubu, Islam, dan Adat, yang dominan dan saling mendominasi. Dari sinilah kemudian dapat ditarik kesimpulan bahwa ketegangan antara Islam dan adat Tolaki sebenarnya sangat jarang ditemui, tidak seperti anggapan sebagian masyarakat Muslim Tolaki di daerah ini. Ketegangan justru muncul ketika Islam diposisikan sebagai ajaran yang ingin mendominasi dan menghilangkan eksistensi budaya lokal, atau melukai harmonisasi budaya lokal dengan Islam seperti yang selama ini terjalin dengan baik (Satria, 2011: 4-5).

Pada prosesi uparaca adat perkawinan (menyangkut sistem perkawinan suku Tolaki dapat dilihat buku Abdurrauf Tarimana, 1993), nilai-nilai Islam 
hadir dalam fragmen acara aqad nikah yang dirangkaikan sesuai dan menjadi bagian integral dari fragment upacara adat Mowindahako (Pernikahan Adat). Dalam fragmen acara aqad nikah tersebut, dilaksanakan prosesi rukun nikah sesuai ajaran Islam, seperti pengucapan kalimat istigfar dan dua kalimat syahadat, khutbah nikah, ijab qabul, serta pembacaan do'a nikah dan shighat ta'lik. Pada fragment upacara adat Mowindahako yang dilaksanakan sebelum acara aqad nikah, prosesi penggunaan kalosara yang dipandu oleh sepasang tolea (Duta Adat) dan pabitara (Juru Bicara Adat), senantiasa diawali dengan ucapan salam dan basmalah, serta di akhiri dengan ucapan Alhamdulillah dan salam penutup.

Hal tersebut dapat terjadi dalam sebuah proses interaksi. Karena, pada setiap kebudayaan terdapat suatu kemampuan untuk bertahan dan menyeleksi pengaruh budaya luar yang diwujudkan dengan penolakan atau mendiamkan. Demikian pula kemampuan mengakomodasi serta kemampuan mengintegrasikan budaya luar kedalam budaya asli.

Interaksi Islam dengan budaya lokal dapat dianalisa dalam konteks sosio historis, seperti yang terjadi dalam pola penyebaran Islam ke kawasan nusantara. Dalam kaitan ini dapat dibedakan menjadi tiga pola penyebaran dan pembentukan formasi Islam yang terjadi pada berbagai daerah di Asia Tenggara.

Terdapat empat pola pembentukan formasi sosial Islam yang mungkin terjadi dalam proses interaksi antara Islam dengan budaya lokal. Pola yang pertama dan kedua merupakan dua varian pola intergratif yang disebut pola Islamisasi. Sedangkan yang kedua disebut sebagai pola pribumisasi. Pola ketiga dan keempat merupakan varian-varian dari pola dialog yang masing-masing disebut sebagai pola negoisasi dan pola konflik.

Pergumulan Islam dengan khazanah lokal menjadikan Islam begitu multiwajah. Ketika ia menjumpai varian kultur lokal, maka yang segera berlangsung ialah aneka proses simbiose yang saling memperkaya. Munculnya berbagai varian Islam: Islam-Jawa, Islam-Sasak, Islam-Melayu, Islam-Madura, Islam-Pesisir, Islam-Poliwali, Islam-Ambon, Islam-Padang, Islam-Banjar, IslamBima, dan seterusnya menggambarkan Islam selalu memiliki warna lokal ketika menghampiri sebuah komunitas. Demikian juga ada Islam-Arab-Islam-Iran, Islam-Cina, Islam-Amerika, Islam India, Islam-Indonesia, dan sebagainya yang masing-masing memiliki konstruk kebenaran sendiri-sendiri. Begitu pula dapat kita munculkan suatu hipotesa konsep "Tolaki Islam dan Islam Tolaki". Dalam konteks Indonesia, lahirnya Kompilasi Hukum Islam (KHI) yang juga 
di dalamnya diadopsi sistem gono gini merupakan dialektika hukum Islam dengan tradisi yang berkembang di Indonesia. Ini merupakan cita-cita lama dari para pemikir hukum Islam di Indonesia yang menginginkan adanya fikih yang berkepribadian Indonesia.

Adanya akulturasi timbal balik antara Islam dan budaya lokal diakui juga dalam suatu kaedah atau ketentuan dasar dalam ilmu ushul al-fiqh bahwa adat itu dihukumkan (al 'adah muhakkamah), atau lebih lengkapnya, adat adalah syariat yang dihukumkan (al-'adah syariah muhakkamah). Artinya, adat dan kebiasaan suatu masyarakat yaitu budaya lokal adalah sumber hukum dalam Islam.

Sebagai suatu norma, aturan, maupun segenap aktivitas masyarakat Indonesia, ajaran Islam telah menjadi pola anutan masyarakat. Dalam konteks inilah Islam sebagai agama sekaligus telah menjadi budaya masyarakat Indonesia. Di sisi lain budaya-budaya lokal yang ada di masyarakat, tidak otomatis hilang dengan kehadiran Islam. Budaya-budaya lokal ini sebagian terus dikembangkan dengan mendapat warna-warna Islam. Perkembangan ini kemudian melahirkan "akulturasi budaya", antara budaya lokal dan Islam.

Pada peristiwa kematian (Ine Mate'aha), nyaris seluruh prosesi pengurusan jenazah menggunakan norma-norma Islam, seperti membaca surat Yasin (mobasa yasi), memandikan (mobaho omate), mengkafani (mondongo omate), menshalatkan (sambahea), hingga tahap menguburkan (Mepotano). Pada proses upacara adat peringatan atas hari kematian (Mo'alowingi atau pepokolapasi'a), nilai-nilai Islam hadir dalam rupa tradisi pengucapan lafadz-lafadz tahlil (Tahalele), tasbih dan do'a-do'a jinayat, serta penyampaian ceramah agama (Ta'ziyah) yang dibawakan oleh seorang ustadz atau muballigh.

Budaya-budaya lokal Tolaki lainnya yang kemudian berakulturasi dengan Islam antara lain acara selametan moalo owinggi (3, 7, 40, 100, dan 1000 hari) di kalangan suku Tolaki. Termasuk acara mepokolapasi atau tahlilan (metaholele) biasanya diambil dari hari-hari tersebut diatas. Pada beberapa hari kematian biasanya keluarga menyajikan makanan bekas tempat mayit dirumah tersebut yang disebut dengan modoriou, hal ini dilaksanakan adanya keyakinan bahwa roh si mayat masih perlu makan dan datang menenggok keluarganya. Dalam konsep kepercayaan orang Tolaki bahwa si mayat benar-benar rohnya telah pergi setelah malam ke empat puluh atau malam ke seratus seiring dengan dilaksanakannya upacara pelepasan atau mepokolapasi dengan kegiatan yang didalamnya ada tahlilan atau metaholele.

Islam sebagai agama yang universal yang melintasi batas waktu kadang 
kala bertemu dengan tradisi lokal yang berbeda-beda. Ketika Islam bertemu dengan tradisi lokal, wajah Islam berbeda dari tempat satu dengan lainnya. Menyikapi masalah ini ada dua hal yang penting disadari. Pertama, Islam itu sebenarnya lahir sebagai produk lokal yang kemudian diuniversalisasikan dan ditrandensi sehingga menjadi universal. Kedua, walaupun kita yakin bahwa Islam itu wahyu Tuhan yang universal, yang gaib, namun akhirnya ia dipersepsi oleh si pemeluk sesuai pengalaman, problem, kapasitas, intelektual, sistem budaya, dan segala keragaman masing-masing pemeluk dalam komunitasnya. Dengan demikian, memang justru kedua dimensi ini perlu disadari yang di satu sisi Islam sebagai universal, sebagai kritik terhadap budaya lokal, dan kemudian budaya lokal sebagai bentuk kearifan (local Wisdom) masing-masing pemeluk di dalamnya memahami dan menerapkan Islam itu.

Berkaitan dengan hal, maka ada istilah Islam universal dan Islam lokal. Ajaran tentang tauhid (pengesaan Tuhan) adalah universal yang harus menembus batas-batas geografis dan kultural yang tidak dapat ditawar-tawar lagi. Sementara itu, ekspresi kebudayaan dalam bentuk tradisi, cara berpakaian, arsitektur, sastra dan lain-lain memiliki muatan lokal yang tidak selalu sama setiap daerah kendati sama-sama beragama Islam.

Studi etnografi belakangan ini menjadi kontemporer (post modern). Ini menunjukan perkembangan yang menggairahkan. Pendekatan etnografis dalam melekatkan fakta-fakta sosial budaya dan keagamaan suatu masyarakat yang begitu beragam dan masing-masing memperlihatkan orisinalitas yang khas, jelas menginspirasi suatu gejala baru, yakni gejala bangkitnya suara yang diam ke permukaan setelah sekian lama terpendam, mengalami marjinalisasi, keterbelakangan, primitif, ketinggalan, dan masih setumpuk tudingan yang mendiskreditkan bahwa kebudayaan lokal, tradisi lokal, dan agama lokal dianggap sebagai entitas sosial budaya yang terbelakang, kumuh, tidak rasional, cermin kebodohan yang tidak memiliki visi kemajuan dan tidak ada evaluatif atau perubahan.

Kehidupan masyarakat Tolaki yang plural, terdapat pengaruh agama-agama besar, teknologi, pendidikan, pengaruh kaum migran Bugis, Jawa, Toraja, dan sebagainya. Akhirakhir ini kita sering disibukkan dengan gugatan, salah satunya yaitu apakah kebudayaan Tolaki bisa dipertemukan dengan ajaran Islam? Pertanyaan tersebut kemudian memunculkan polarisasi sikap dan pandangan masyarakat Tolaki terhadap kebudayaan Tolaki jika dikaitkan dengan ajaran Agama Islam.

Pertama, kebudayaan Tolakibisa dipertemukan dengan ajaran Islam. Hal ini tampak pada acara-acara adat Tolaki, dimana unsur Islam berpadu dengan budaya sebagaimana 
penulis telah jelaskan. Kedua, budaya Tolaki tidak bisa dipertemukan dengan ajaran Islam. Budaya Tolaki dengan unsur Kalosaranya dianggap bid'ah, sesuatu yang sesat dan bertentangan secara diametral dengan Islam sejati. Selanjutnya, kelompok pendukung gagasan ini menganggap bahwa mempertahankan dan mempraktekkan budaya/tradisi Tolaki yang notabene merupakan warisan nenek moyang dianggap sebagai kesesatan dan cenderung kepada kekafiran. Pandangan kedua ini cenderung ekstrim dalam melihat keterkaitan budaya dan Agama (Islam), dan ketiga, Islam dan budaya Tolaki tidak ada masalah, artinya keduanya bisa dipertemukan dan bisa pula dipertentangkan. Polarisasi pandangan masyarakat Tolaki terhadap kebudayaannya memungkinkan terjadi karena perubahan masyarakat yang terus menerus terjadi secara meluas. Tahapan perkembangan dan perubahan budaya memungkinkan masyarakat bersikap terhadap tradisinya sendiri. Terkait dengan hal ini, Suparlan mengemukakan bahwa dinamika atau ekses perubahan sosial pada komunitas tertentu memungkinkan terjadinya seperti hal-hal sebagai berikut (Satria, 2011: 5):

Pertama, Mereka berusaha meninggalkan atau membuang tradisi-tradisi kebudayaan mereka, karena mereka melihat tradisi-tradisi tersebut sebagai atribut yang tidak menguntungkan bagi jati diri atau identitas mereka dalam berinteraksi dengan golongan etnik atau suku bangsa lainnya, dan bagi kemajuan tingkat sosial, ekonomi, dan kebudayaan yang ingin mereka capai. Sebagai gantinya mereka mengadopsi kebudayaan atau unsur-unsur kebudayaan lainnya yang mereka lihat sebagai dominan dalam struktur hubungan antar kebudayaan yang berlaku dalam masyarakat di mana mereka tinggal.

Kedua, mereka secara spesifik melarikan diri lebih jauh dari pusat-pusatberlakunya kontak kebudayaan dengan dunia luar dan dari kontakkontak dengan kebudayaan yang lebih maju, sehingga secara kebudayaan mereka terbebas dari pengaruh kebudayaan luar yang dirasakannya sebagai beban kejiwaan dan mental karena merasakan kecilnya harkat dan martabat kemanusiaan mereka dalam kerangka acuan kebudayaan luar tersebut.

Ketiga, Kehidupan komunal dan solidaritas sosial mengalami disorganisasi atau bahkan mengalami disintegrasi karena mekanisme kontrol yang ada di dalam kebudayaan mereka yang tidak dipergunakan. Masyarakat Tolaki dengan segenap kebudayaannya merupakan system of boundary yang tak pelak harus berhadapan dengan perubahan. Perubahan sosial yang terjadi disebabkan oleh modernisasi dan agama baru atau ideide baru. Proses Islamisasi di Sulawesi Tenggara, utamanya pada masyarakat Tolaki berbarengan dengan upaya peminggiran budaya lokal dan/atau bahkan inkulturasi dengan budaya Tolaki. Peminggiran budaya lokal (budaya Tolaki) berbarengan dengan munculnya paham keislaman baru yang berkembang ditengah masyarakat. Tetapi pada saat bersamaan, paham keagamaan (Islam) tertentu masih terus berupaya mengadopsi budaya lokal, khususnya dalam kerangka 'pribumisasi Islam di tanah Tolaki'. 
Inkulturasi Islam dengan budaya Tolaki dapat disaksikan pada acara adat perkawinan Tolaki (perapua). Pada acara ini unsur Islam dan budaya memperlihatkan bentuk pemaduan atau inkulturasi. Islam menemukan manifestasinya dalam proses inkulturasi dengan budaya Tolaki di beberapa Kabupaten di Sultra, khususnya dalam upacara adat perkawinan Tolaki. Dalam studi kebudayaan lokal, inkulturasi mengandaikan sebuah proses internalisasi sebuah ajaran baru ke dalam konteks kebudayaan lokal dalam konteks akomodasi atauadaptasi. Inkulturasi dilakukan dalam rangka mempertahankan identitas. Dengan demikian, inkulturasi Islam dengan kebudayaan lokal mirip dengan apa yang dikemukakan oleh K. H. Abdurrahman Wahid sebagai 'pribumisasi Islam'. Pribumisasi di sini dimaksudkan dalam rangka memberi warna Islam terhadap kebudayaan lokal. Islam, dari sisi ini, tidak bertentangan dengan budaya lokal. Tetapi keduanya saling menyesuaikan dan saling mengisi. Relasi Islam dengan kebudayaan lokal, utamanya kebudayaan Tolaki, memperlihatkan sebuah kecenderungan adaptasi kultural. Adaptasi, merupakan proses di mana organisme atau kelompok-kelompok organisme, melalui perubahan-perubahan responsif dalam keadaan, struktur atau komposisinya, sanggup mempertahankan homeostasis di dalam dan di antara mereka sendiri untuk menghadapi fluktuasi lingkungan jangka pendek atau perubahan-perubahan jangka panjang pada komposisi atau struktur lingkungannya. Seiring dengan hal tersebut, Harding mengatakan bahwa dalam teori evolusi, adaptasi berkaitan dengan bukan hanya hubungan antara masyarakat dan alam, namun juga denganusaha 'saling menyesuaikan di antara masyarakat sendiri' (Satria, (2011: 6).

Adaptasi dengan alam akan membentuk teknologi budaya dan secara derivatif juga menciptakan komponen sosial berikut perangkat ideologisnya. Tapi adaptasi dengan budaya-budaya lain bisa membentuk masyarakat dan ideologi, yang pada gilirannya bertindak berdasarkan teknologi dan menentukan masa depannya. Keseluruhan akibat proses adaptif tersebut adalah produksi suatu keutuhan budaya yang terorganisir, suatu teknologi terpadu, masyarakat dan ideologi, yang berhadapan dengan pengaruh selektif ganda alam di satu pihak dan di pihak lain dampak budaya-budaya luar" (Satria, 2011: 4).

\section{Kinoho Agama (Puisi atau nasehat agama): Antara Sastra Tolaki dan Nilai Islam}

Dalam bidang seni sastra, juga dijumpai proses interaksi yang melahirkan akulturasi antara Islam dan budaya Tolaki seperti dalam kesenian Taenango. Isinya tentang peranan seorang tokoh dalam penyebarkan Islam, munculnya Taenango ini diperkirakan sekitar abad ke-16 yang dinyanyikan oleh pande anggo. Proses Islamisasi tidak menghapuskan kesenian ini, melainkan justru 
memperkayanya, yaitu memberikan warna nilai-nilai Islam di dalamnya. Interaksi antara budaya Tolaki dengan nilai Islam tidak hanya dalam bidang seni, tetapi juga di dalam bidang-bidang lain di dalam masyarakat Tolaki. Dengan kata lain kedatangan Islam di tanah Tolaki dalam taraf-taraf tertentu memberikan andil yang cukup besar dalam pengembangan budaya lokal.

Ineraksi Islam dalam bidang seni dan sastra Tolaki yaitu dalam bidang puisi berupa munculnya kinoho agama, atau lolamoa (pantun di bidang agama khususnya Islam). Kinoho agama adalah salah satu jenis puisi (kinoho) yang biasa dijumpai dan ungkapan pada acara bersifat ritual atau keagamaan, seperti baca doa (mobasa o'doa), selamatan, dan tahlilan (taholele). Acara dimulai dengan penyampaian atau nasehat dari pemuka agama yang didalamnya mengungkapkan puisi kinoho.

Contohnya:

Keno otandato dunggu terondo,

Jika tanda telah mendahului

Dungguito mberano banggo-banggo, Sampailah atas sarung di dada

Keno malaekato meori nggombule, Dan kalau Malaikat telah memanggil pulang

To'ono notulei tomotanggo-tanggo,

Tidak dapat ditangguhkan lagi

Kotupa Nabi keno kinondo, Ketupat nabi jika dipandang

Hende Watumetala ineteteaha, Bagai batu berjejer di titian

Peoliwini Nabi niniwatuakondo

Iamo totekolupe lako inemateaha

Berpesan nabi yang kita junjung Jangan lupa kematianmu.

Masih banyak lagi contoh kinoho agama yang hidup dikalangan masyarakat Tolaki. Pantun ini muncul seiring dengan masuknya agama Islam di wilayah ini. Kinoho agama adalah pantun isinya menggambarkan pujian, cemohan, dan sindiran dalam agama. Kinoho agama ini hidup pada masa lalu, akan tetap sekarang sudah langkah bahkan sudah susah kita temukan orang mengungkapkan kinoho agama. Saling menasehati dalam agama Islam adalah hal yang utama sebagaimana firman Allah dalam surat al Asr ayat 1-3. Apalagi nasehatnya menggunakan kinoho yang mudah dipahami oleh masyarakat Tolaki.

Selain itu dalam bidang sastra terdapat dalam sastra lisan berbentuk puisi seperti: Taenango (lagu yang mengisahkan kepahlawanan), lagu taenango 
yang terkenal di kalangan orang Tolaki adalah Tebaununggu, yang mengisahkan peristiwa penyebaran agama Islam dari Aceh ke Indonesia bagian Timur hingga di tanah Konawe Tolaki, Isara yang mengisahkan perang total di darat dan udara dalam usaha memberantas segala kejahatan yang pernah melanda orang Tolaki (Rahmawati, dkk, 2007:15). Ada juga mengisahkan seorang tokoh yang menyebarkan agama Islam di tanah Tolaki yaitu Langgai Saranani.

\section{Islam dalam Dinamika dan Aktivitas Sosial Budaya Tolaki}

Kaitannya dengan aspek-aspek historis dan dominasi jumlah penganut, Islam telah sekian lama menjadi agama populis bagi warga Tolaki, bahkan telah mengkristal menjadi "seolah-olah" agama resmi orang Tolaki. Secara historis, Islam telah dianut oleh warga Tolaki sejak abad ke-XVII M, jauh sebelum agama Kristen hadir di tanah Tolaki. Ketika Raja Mokole Lakidende gelar Sangia Ngginoburu resmi menerima dan masuk Agama Islam, secara sosio-politis telah dilegitimasi menjadi agama resmi kerajaan. Ada suatu hipotesa baru bahwa agama Islam sudah masuk di pesisir wilayah Konawe Utara sekitar abad ke-XV yang dilaksanakan oleh pedagang muslim Ternate dan Bugis (Melamba, 2011: 160). Sebelumnya bias-bias pengaruh pemerintahan Hindia Belanda masuk di tanah Tolaki tahun 1885, tak satupun warga Tolaki yang tercatat beragama lain selain Islam. Selanjutnya pada tahun 1915/1916 Agama Kristen Protestan masuk di daerah Kendari dan Kolaka.

Meski demikian, Islam tidak serta-merta hadir menggantikan sistem kepercayaan lama atau budaya lokal. Banyak praktek-praktek peribadatan politeis atau dinamisme masih mewarnai kehidupan keagamaan warga Tolaki sejak masa lalu, bahkan hingga saat ini masih berlangsung. Sebagaimana pada kelompok etnik lainnya di Nusantara, Islam dalam pandangan orang Tolaki lebih merupakan sistem kepercayaan monoteistik yang hadir membaur atau mengalami internalisasi kedalam sistem kepercayaan klasik yang telah lebih dulu eksis dan dianut secara turun-temurun. Dengan kata lain, Islam dalam persepsi rata-rata warga Tolaki tidaklah secara terus menerus menjadi satusatunya pilihan kepercayaan yang dianut untuk menjadi kerangka kultural dalam membangun perilaku individu ataupun tatanan kehidupan sosial masyarakat, melainkan hanya menjadi bagian dari kompleksitas sistem kepercayaan yang sudah ada dan telah lama hadir melandasi bangunan perilaku individual dan kolektifitas sistem kesatuan hidup masyarakat. Sehingga, apa yang dikenal dengan istilah sinkritisme, yakni sistem kepercayan campuran antara unsur-unsur agama (Samawi) dengan unsur-unsur kepercayaan klasik, 
seperti yang banyak dijumpai pada masyarakat Jawa, juga sering dijumpai pada masyarakat Tolaki. Praktek-praktek sinkritisme di kalangan warga Tolaki antara lain terlihat pada prosesi upacara adat menanam padi, mosehe wonua, upacara siklus pertanian yang disebut lulo ngganda di Desa Benua Kecamatan Benua Kabupaten Konawe Selatan.

Dalam konteks kehidupan sehari-hari, internalisasi nilai-nilai dan simbolisme Islam sangat mencolok terlihat pada beragam tradisi Barasandi atau barsanji atau aqiqah, upacara adat perkawinan (mepakawi), kematian, doa tolak bala (Metula Bala), doa syukur atau hajatan khusus (Mbasa-basa), sunatan (Pewaka'a), upacara pengislaman (Manggilo), upacara khatam Qur'an (Mekhatamu Quraani), dan sebagainya.

Dalam konteks peribadatan khusus (Liturgik), sumber-sumber pengetahuan dan keilmuan Islam warga Tolaki, utamanya di pedesaan, lebih banyak merujuk pada tata cara yang diwariskan oleh orang-orang tua terdahulu atau dari orangorang yang pernah belajar kepada para guru sepuh (Mepaguru) di daerah lain, dan karenanya sangat sedikit yang mengambil langsung dari sumber-sumber Islam yang asli, seperti dari al Quran dan Hadits Nabi, atau dari kitab-kitab rujukan utama kaum muslimin lainnya. Seperti : Kutubush Shitta (Tujuh kitab hadits shahih), Al Umm (Karya Imam Syafy'i), Ash-Shahihain (Kitab hadits Mukhari Muslim), Bulughul Maram, Riyaadush Shalihiin, Ihya Ulumuddin, dan lain-lain. Sehingga, di lingkungan kelompok etnik ini, dikenal adanya ceritacerita klasik tentang orang-orang terdahulu yang memiliki kesalihan peribadi setelah menimba ilmu pengetahuan Islam (biasanya ilmu ladunni) lewat jalan bersemedi, atau melalui prosesi "Belajar di dalam kelambu" (Mepaguru I Une Kulambu), atau melalui proses berguru di tanah Jawa, di tanah Bugis atau di tanah Mekkah.

Selain pada beberapa event budaya dan peribadatan khusus di atas, nilai-nilai Islam dalam masyarakat Tolaki juga muncul dalam rupa simbolisme perayaan hari-hari besar Islam yang dilaksanakan setiap tahun, seperti Maulid Nabi (Maulu nabi), Nuzulul Quran dan Isra Mi'raj. Pada hari raya Idul Fitri atau Idul Adha, dikenal adanya tradisi masiara, yakni tradisi sillaturrahmi atau saling kunjung mengunjungi antar sesama anggota keluarga, dan kerabat terdekat. Dari beberapa kegiatan yang bernuansa Islam biasanya dikalangan ibu rumah tangga menyajikan sungguhan makanan salah satunya kotupa nabi atau ketupat nabi sebagai ciri khas.

\section{Agama Islam Wasilah Integrasi Sosial orang Tolaki}


Dinamika keberagaman internal di lingkungan orang Tolaki di atas, agama Islam pada konteks dinamika sosial kemasyarakatan secara umum di ranah budaya Tolaki, secara turun-temurun telah menjadi salah satu faktor perekat utama, atau dapat dikatakan telah menjadi semacam kalimatush shawa (Kalimat pertengahan dalam istilah Nurcholis Majid) yang merekatkan integrasi sosial atau memfasilitasi titik-titik kedekatan sosial secara "cukup signifikan" antara entik Tolaki dengan kelompok etnik lainnya, termasuk dengan kelompok etnik Bugis-Makassar. Nilai-nilai Islam yang bersifat universal (tidak mengenal batas-batas geo-kultural) dirasakan cukup aplikatif dalam "mendamaikan" titik-titik perhimpitan kepentingan sosial antar warga.

Kesamaan nilai-nilai panutan Islami antara warga muslim Tolaki dan warga muslim dari kelompok etnik lainnya, secara turun-temurun telah terinternalisasi ke dalam kompleks kesamaan dan kebersaman sosial sehari-hari, seperti orang Tolaki dan orang Bugis sama-samk tidak makan babi, sama-sama tidak suka memelihara anjing, sama-sama memiliki rasa malu (Kohanu bagi orang Tolaki dan Sirri di kalangan orang Bugis), sama-sama suka masiara (Sillaturrahmi Idul Fitri dan Idul Adha), sama-sama shalat, puasa dan naik haji, sama-sama suka merayakan peringatan hari besar Islam, sama-sama suka bersanji, sama-sama "Merasa diharuskan" oleh adat dan orang-orang tua untuk kawin dengan sesama muslim, serta norma-norma kesamaan sosial yang bersifat integratif lainnya. Ada tradisi yang berkembang bahwa larangan makan babi dikalangan Tolaki berdasarkan pada cerita rakyat bernuansa agama, bahwa pada saat nabi Muhammad SAW makan, istri beliau Siti Hadijah lupa menyajikan daging babi tersebut", namun ini hanya folklore yang berkembang, tetapi yang mengerti fikih paham bahwa binatang bertaring diharamkan. Itulah fenomena pengetahuan tradisi dan agama yang berkembang dikalangan suku Tolaki.

\section{Menunaikan Ibadah Haji Sebagai Orientasi dan Paradigma}

Salah satu keunikan yang ada pada suku tolaki yang dijumpai pada kelompok etnik lain,terutama etnik Bugis-Makassar, adalah bahwa haji di kalangan warga Tolaki bukanlah merupakan bagian dari kesadaran sosiokultural yang mapan misalnya, mewarisi tradisi keberagaman orang-orang tua terdahulu. Pada etnik Bugis-Makassar, naik haji telah menjadi tradisi turun temurun yang secara visual berhasil mengintegrasikan tiga jenis orientasi nilai sekaligus yakni, (1) orientasi nilai sosial sebagai salah satu simbol kemapanan ekonomi dan karenanya menjadi target mobilitas sosial ekonomi seseorang untuk meraih status sosial tertentu dalam masayrakat, (2) orientasi nilai 
ritual (persembahan/pengorbanan) sebagai prasarat trasendetal untuk meraih keberkahan ekonomi yang lebih mapan, serta (3) orientasi nilai liturgik (penunaian nilai agama) sebagai simbol rasa syukur dan pemenuhan kewajiban keislaman puncak kepada Tuhan. Ketiga orientasi nilai ini diyakini akan menambah 'keberkahan' seseorang dalam mengarungi hidup dan kehidupannya di atas dunia ini. Sehingga, dalam kehidupan sehari-hari orang Bugis-Makassar, selalu dijumpai kenyataan bahwa seorang rela membanting-tulang dan menguras keringat siang dan malam dalam mengumpulkan rupiah demi rupiah, hanya untuk memenuhi obsesi menunaikan ibadah haji (Taridala, 2005: 130).

Di kalangan suku Tolaki, kecuali pada beberapa gejala sosial baru dalam dasawarsa terakhir, menunaikan ibadah haji relatif tidaklah menjadi tradisi ataupun obsesi klasik yang diorientasikan sebagai simbol kemapanan sosial ekonomi seseorang dan sekaligus meningkatkan status sosial, beberapa kalangan Tolaki sangat bangga di panggil dengan panggilan "pak, Haji, bu Hajjah”. Ia juga secara visual, tidak begitu nampak menjadi bagian dari orientasi nilai ritual yang didedikasikan untuk meraih keberkahan ibadah maupun ekonomi. Naik haji di kalangan (kebanyakan) orang Tolaki relatif lebih diorientasikan sebagai kewajiban agama (liturgik) yang bernuansa mistis untuk meraih apa yang secara turun temurun dipercaya sebagai prasarat memperoleh kesalehan individual dan kekuatan supranatural. Seorang yang menunaikan ibadah haji dipersepsikan sebagai mereka yang memiliki kesiapan batin untuk belajar, berguru, atau berkontemplasi di tanah suci Mekkah guna memperoleh ilmu Ladunni (ilmu ketuhanan) atau pesan-pesan ilahiyah yang bersifat aplikatif untuk dibawa pulang ke kampung.

Orientasi nilai atau mistifikasi 'haji' seperti itu, yang lalu mewariskan beragam hikayat klasik di kalangan orang Tolaki tentang para haji (hadi mabaraka ako) terdahulu yang diberitakan memiliki kelebihan-kelebihan transcendental, supranaturalistik atau semacam kedigdayaan tertentu (mondoriako) dengan tampilan sifatnya afektif kasuistik yang supra-manusiawi, seperti mampu menghilang (mesawurondo), dapat terbang atau berjalan di atas air, mampu 'meramal' masa depan, dapat mengobati penyakit kronis, dapat menggandakan eksistensi diri dalam waktu yang sama beberapa ruang yang berbeda, dan lain-lain.

Salah satu figur populer tentang 'haji mabaraka atau mondoriako' di kalangan orang Tolaki dikenal adanya cerita klasik tentang seseorang yang menempuh perjalanan haji selama berbulan-bulan di atas lautan lepas dengan mengendarai perahu layar sederhana. Sebelum berangkat, orang tersebut 
mempersiapkan cukup lama, baik persiapan yang bersifat batiniah, termasuk proses penggemblengan diri dengan berbagai ilmu khusus, maupun persiapan yang berupa bekal perjalanan, termasuk makanan, dan pakaian.

Dalam kurun waktu satu atau dua dekade terakhir, mulai terdapat gejala pergeseran nilai dan orientasi naik haji di kalangan orang Tolaki, yakni bahwa rukun Islam yang kelima itu telah mulai dipandang sebagai salah satu simbol status sosial atau simbol kemapanan ekonomi, disamping tentunya masih juga dipandang sebagai simbol kesalehan pribadi. Meski demikian, warga masyarakat yang menunaikan ibadah haji masih terbatas pada keluarga-keluarga pejabat publik (birokrat dan politisi), para petani kaya (patani nggawasa), atau para pemilik harta waris yang cukup besar. Sedangkan warga Tolaki dari kalangan pedagang atau kelompok professional, masih jarang tercatat menunaikan ibadah haji. Pejabat publik yang berangkat haji biasanya menggunakan dana tabungan sendiri (biasanya juga dari hasil pengundian arisan keluarga), dari hasil panen raya, atau karena jabatan dan kedudukannya, menggunakan fasilitas bantuan dana pemerintah, atau hasil dari penjualan asset tertentu, misalnya tanah/rumah, kebau, kebun, dan sebagainya.

\section{Aktivitas Sosial dan Masjid-Masjid Orang Tolaki}

Masuk dan berkembangnya Islam di daerah Konawe dan Kolaka membawa perubahan dalam berbagai aspek kehidupan masyarakat. Dolmen atau petirtaan tidak dibangun lagi, tetapi kemudian muncul masjid, Surau, Musholla, dan makam. Menurut C.H. Pingak, masjid raya Kolaka dapat diketahui pasti telah dibangun sejak tahun 1951 dan selesai tahun 1963, maka di daerah Konawe, tidak ada informasi akurat yang menyebutkan tahun pastinya pendirian masjid. Menurut sumber sejarah, masjid pertama yang dibangun dan tercatat sebagai yang tertua di tanah Konawe terletak di desa (sekarang kelurahan) Parauna Kecamatan Anggaberi (tidak diketahui, tahun berapa dan siapa tokoh utama yang menggagas pendirian masjid ini (Endraswara, 2003: 11).

Masjid-masjid tua lainnya di tanah Tolaki umumnya digagas pendiriannya pertama kali oleh para penyiar Islam atau para guru mengaji dari berbagai daerah di tanah air, terutama daerah Sulawesi Selatan. Mereka berpindah-pindah dari satu kampung ke kampung lainnya, dan ketika menetap di sebuah kampung selama kurun waktu tertentu, bersama-sama dengan masayrakat setempat, mereka memprakarsai pendirian masjid. Arsitektur bangunan masjid, baik di Kabupaten Kendari maupun di Kabupaten Kolaka, seluruhnya identik dengan arsitektur klasik masjid-masjid di Sulawesi Selatan dan daerah lainnya, yang 
antara lain ditandai dengan adanya kubah. Beberapa masjid yang menggunakan arsitektur Jawa (terutama model masjid demak), merupakan masjid yang dibangun dari dana bantuan Yayasan Amal Bakti Muslim Pancasila.

Masjid-masjid diperkampungan warga Tolaki umumnya dibangun dengan kontruksi sederhana, dan relatif kurang merefleksikan adanya spirit religius yang cukup intens untuk mendahulukan pembangunan masjid daripada pembangunan sarana lainnya. Artinya, berbeda dengan, misalnya umumnya perkampungan Bugis-Makassar di mana dibangun masjid relatif lebih megah dibanding bangunan lainnya (rumah, balai desa, dll), di perkampungan warga Tolaki, bangunan masjid sering dijumpai tidak lebih megah dengan bangunan rumah warga atau balai desa. Berbeda ketika melihat bangunan-bangunan masjid yang megah dan dipenuhi dengan lukisan atau ukiran kaligrafi yang indah. Secara tidak langsung, fakta tersebut mencerminkan adanya proses asimilasi yang kemudian menghasilkan sebuah karya seni yang dahulunya dapat dijumpai pada peninggalan sejarah, sedangkan pada saat ini terlihat dalam bentuk keindahan yang juga merupakan karya seni pada masjid-masjid yang ada di Indonesia.

Pada sisi lain, secara fisik akulturasi budaya yang bersifat material dapat dilihat pada: pembangunan masjid yang diawali dengan syukuran (mobasabasa), ataupun upacara tolak bala atau metula bala/mosehe. Sementara esensi Islam terletak pada "ruh" fungsi masjidnya. Masjid yang di bangun pertama di tanah Tolaki Konawe adalah bernama masjid Salasa di Kerajaan Konawe tepatnya di kampung Parauna (Melamba, 2011: 162). Khusus di daerah Sulawesi Tenggara, proses akulturasi ini antara lain dapat dilihat dalam acara-acara seperti selamatan, penguburan, upacara perkawinan, dan sebagainya. Acara tersebut biasa dilaksanakan di masjid. Umumnya pada masa lalu arsitek masjid yang dibangun umumnya berbentuk punden berundak-undak salah satu contoh masjid yang di bangun oleh tokoh penyebar agama Islam di daerah Konawe Utara Haji Laasamana (dikenal Tua Hadi, 1886-1921) membangun masjid dengan model punden berundak undak diatas puncak masjid di pasangkan guci atau tempayan (Wawancara, Daniel Bunggulawa, hasil observasi lapangan). Model bangunan punden berundak-undak merupakan unsur peninggalan prasejarah, hal ini ini dapat diperhatikan bangunan menara Kudus. Bahkan setiap awal pembangunan masjid di setiap tiang raja diatasnya ditempatkan satu tandan pisang, jika sudah masak baru diperbolehkan mengambilnya itupun kulitnya tidak dikupas tetap melekat pada tangkainya, yang dilepas hanya isi buah pisang, tandan dan kulitnya dibiarkan mengering, hal bermakna agar 
masjid dingin laksana dinginnya pohon pisang.

Beberapa masjid yang dijumpai cukup mewah pada perkampungan warga Tolaki, umumnya merupakan bangunan lama yang direnovasi atau dibangun dalam kurun waktu yang cukup lama. Nyaris tidak ada masjid mewah di lingkungan etnik ini yang dibangun secara sekaligus tanpa melalui tahapan yang panjang. Contoh paling klasik dari kasus ini adalah pembangunan Masjid Raya Unaaha yang tidak kunjung rampung hingga kini, meski telah dibangun sejak tahun 1990, yakni sejak Bupati Kendari dijabat oleh Drs. H. Anas Bunggasi. Sisi dan jumlah menara masjid berjumlah 4 (empat) buah, hal ini dianalogikan sebagai simbol struktur pemerintahan Siwole mbatohu (empat wilayah sayap atau barata pemerintahan kerajaan Konawe, serta tiang utama berjumlah tujuh buah disimbolkan Opitu dula Batuno Konawe atau tujuh orang anggota dewan kerajaan Konawe.

Relatif minimnya spirit religius di masjid-masjid Tolaki juga terlihat dari aktifitas pengurus atau jama'ah Masjid yang umumnya hanya mengikuti rutinisme ibadah khusus, seperti shalat jama'ah, berzikir, atau membaca wirid dan bertadarus (membaca al Quran). Hal itu pun kebanyakan dilakukan dengan intensitas dan frekuensi yang relatif cukup minim, seperti shalat jama' ah hanya dilakukan pada waktu Magrib dan Isya, atau pada hari Jum'at dari hari raya idul fitri dan idul adha saja, itupun dengan jumlah jama'ah yang relatif sedikit. Bahwa, sebagaimana dalam konsep Islam, masjid tidak hanya berfungsi ritual sebagai tempat melaksanakan ibadah khusus, melainkan juga dapat berfungsi sosial (misalnya sebagai pusat pendidikan dan urusan mu'amalah lainnya), umumnya belum begitu teraplikasi pada masjid-masjid di lingkungan warga Tolaki. Hal ini sesungguhnya terkait erat dengan sangat kurangnya da' i, ustadz, muballigh, imam masjid, atau aktifis-aktifis pemuda Islam dengan tingkat pengetahuan Islam dan semangat dakwah yang memadai di lingkungan warga Tolaki, para petugas rutin yang setia memakmurkan masjid, seperti guru mengaji, imam shalat, khatib Jum'at (Katibi), tukang adzan (Bilala), bahkan sampai penjaga masjid, banyak diantaranya bukan warga Tolaki.

Jika diobservasi masjid-masjid dikampung saat setiap shalat banyak yang pasif. Namun hari Jumat, kegiatan maulid nabi (maulu), Isra Mi'raj, atau hari Raya Idul Fitri atau Idul Adha. Secara empiris sebagian masyarakat Tolaki dalam hal ibadah shalat yang memiliki pandangan bahwa dalam menjalankan sholat bahwa cukup sholat di dalam hati, atau melalui niat semata, tak perlu sholat mulai dari niat takbirutul ihram sampai salam. Dalam beberapa wawancara dengan tokoh agama dan masyarakat mengungkapkan masih 
terdapat masyarakat Tolaki yang menganut paham ini. Melalui sholat dalam hati dianggap telah melaksanakan sholat. Kasus diatas mirip jika dibandingkan dengan kasus di Jawa.

\section{Dialog Budaya Tolaki dalam Khazanah Teori Budaya}

Manusia adalah makhluk bio-fsikologis, yaitu makhluk yang memiliki unsur biologis berupa raga atau fisik, sekaligus juga punya unsur psikologis atau kejiwaan. Sebagai makhluk biologis manusia membutuhkan materimateri untuk kelangsungan hidupnya tersebut yang disebut sebagai kebutuhan dasar manusia (basic human needs). Secara psikologis, manusia ingin selalu membutuhkan rasa aman dan tenteram yang diperoleh melalui kehidupan bersama sosial (Malinowski, 1960: 59). Oleh karena itu manusia dapat dilihat sebagai makhluk individu dan sosial. Untuk sampai pada pemenuhan kebutuhan tersebut, maka manusia menciptakan kebudayaan. Menurutnya setiap unsur kebudayaan yang terdapat dalam masyarakat manusia, tidak lain adalah untuk memenuhi kebutuhan hidup manusia (baik biologis maupun psikologis). Dengan kata lain, setiap unsur kebudayaan itu berfungsi untuk memenuhi kewajibannya yaitu memenuhi needs demi kelangsungan hidup manusia. Bagi Malinowski, dalam rangka memenuhi kebutuhan psiko-biologis individu dan menjaga kesinambungan hidup kelompok sosial, beberapa kondisi minimum harus dipe nuhi oleh individu-individu anggota kelompok sosial tersebut. Kondisi minimum tersebut terdiri dari 7 kebutuhan pokok, yaitu nutrition, reproduction, bodily conforts, safety, relaxation, movement, dan growth. Semua kegiatan yang dilakukan oleh individu adalah dalam rangka memenuhi ke-7 kebutuhan pokok di atas.

Eksistensi barasandi sebagai produk budaya lokal orang Tolaki dan aktivitas sosial keagamaan lain seperti budaya perkawinan (mepakawi), kematian (mateaha), menunaikan ibadah haji, mendirikan masjid, dan sebagainya tidak terlepas dari upaya pemenuhan basic need tersebut. Budaya barasandi misalnya, dilaksanakan dalam rangka tercapainya kebutuhan akan keselamatan sebagaimana pribadi Nabi Muhammad SAW yang konsekuen dalam merealisasikan syari'at Islam. Demikian pula halnya dengan ritual kematian, ibadah haji, mendirikan masjid, dan sebagainya. Sedangkan budaya perkawinan, dilaksanakan untuk memenuhi kebutuhan akan reproduksi dan pertumbuhan generasi.

Kegiatan untuk memenuhi kebutuhan pokok tersebut tidaklah langsung dilakukan begitu saja sebagaimana halnya dengan binatang, tetapi telah "dimodified” oleh pengaruh-pengaruh sosial. Dalam rangka untuk memenuhi 
kebutuhan safety (keselamatan) misalnya, manusia tidak begitu saja dilakukan dengan cara semaunya. Manusia terikat dengan norma dan nilai yang ada di lingkungan sosialnya, seperti agama, adat-istiadat dan sebagainya.Ia akan memilih di antara jalan-jalan keselamatan tersebut dengan hati-hati; sebab ada yang ditolak dan ada yang diterima, ada yang dianjurkan dan ada yang dilarang, dan seterusnya. Jadi tingkah laku manusia dalam memenuhi kebutuhan akan psikologis tersebut telah terbentuk oleh cara-cara yang lazim sesuai dengan adat kelompok mereka, sesuai dengan agama mereka, sesuai dengan kelas sosial mereka, dan seterusnya. Kelompok, golongan, dan kelas sosial telah membentuk pilihan selera individu, Pola kegiatan yang telah terbentuk seperti itu disebut "kegiatan kultural", yaitu kegiatan yang telah dimodifikasi oleh adat kebiasaan yang hidup dalam lingkungan masyarakatnya.

Pelaksanaan upacara Barasandi misalnya telah dilaksanakan modifikasi dengan perpaduan tradisi dan syariat Islam. Aktivitas ini memiliki relasi dengan norma dan nilai adat dan agama. Dalam melaksanakan upacara kematian, perkawinan, dan beberapa aktivitas social misalnya menunaikan haji,selain mengikutiadat kebiasaan yang hidup dalam lingkungan masyarakatnya, juga mengikuti tradisi Islam.

\section{Simpulan}

Proses interaksi, persenyawaan keislaman dengan budaya, menjadikan Islam yang ada di kalangan Tolaki, mudah diterima oleh masyarakat. Tidak ada resistensi; yang ada adalah penyambutan. Sungguhpun ada modifikasi, itu tidak lebih pada injeksi nilai-nilai keislaman dalam tradisi yang telah ada.

Interaksi Budaya Tolaki dengan Islam menghasilkan dua bentuk. Pertama, Islam mewarnai, mengubah, mengolah, dan memperbaharui budaya lokal Tolaki. Pola ini memunculkan budaya Barasandi atau aqiqah, yang sejalan dengan nilai Islam. Bukti nyata dari proses persenyawaan antara Islam dan budaya lokal dalam bidang kehidupan masyarakat Tolaki dapat ditemukan dalam bentuk acara Barasandi yang sejalan dengan nilai Islam. Kedua, Islam mewarnai budaya lokal. Melalui hal ini muncul proses budaya yang bernuasa Islam dalam hal aktivitas perkawinan mowindahako, upacara kematian (mateaha) selamatan (moalo owingi), menunaikan ibadah haji (Hadi kobaraka), kehidupan keagamaan dan organisasi social. Budaya selamatan (mobasa-basa), Maulid Nabi (Maulu nabi), Yasinan (yasina), sunatan (Manggilo), aktivitas keagamaan, dan orientasi menunaikan ibadah haji.

Proses perpaduan Islam dan budaya lokal dalam beberapa aspek kehidupan 
juga bermacam-macam, namun secara luas dapat dimaknai sebagai proses interaksi, akulturasi, asimilasi dan singkretisasi. Sungguhpun demikian, yang lebih menjadi sorotan adalah; bahwa perpaduan budaya Islam dan budaya lokal di bidang seni dan sastra telah memberikan konstribusi besar dalam perjalanan dan perkembangan Islam di Tolaki seperti kinoho agama, anggo nabi. Agama dan Budaya memiliki kaitan yang sangat erat, yakni agama berperan sebagai konsepsi budaya dan sebagai realitas budaya yang terdapat di Nusantara.

Budaya merupakan hasil dari interaksi antara manusia dengan segala isi yang ada di alam raya ini. Dengan semua kemampuan yang dimiliki oleh manusia maka manusia mampu menciptakan suatu kebudayaan. Kebudayaan digunakan untuk memahami agama yang tampil dalam bentuk formal yang menggejala di masyarakat. Keragaman budaya atau cultural diversity adalah keniscayaan yang ada di wilayah ini, dan tidak dapat dipungkiri keberadaannya.

\section{Daftar Pustaka}

Malinowski, Branislaw. 1960. A Scientific Theory of Culture and Other of Essays. A Galaxi Book: Oxford University Press, New York.

Melamba, Basrin, dkk. 2011. Sejarah Tolaki di Konawe. Yogyakarta: Teras.

Melamba, Basrin, dkk. 2012. Tolaki: Sejarah, Indentitas, dan Kebudayaan. Yogyakarta: Lukita.

Satria, Muh. 2011. Mempertimbangkan Kembali Inkulturasi Islam Dalam Perkawinan Adat Tolaki Di Kabupaten Konawe. Kendari: Fakultas Hukum Unhalu.

Purwadi, dkk. 2005. Mistik Kejawen Pujangga Ronggowarsito. Yogyakarta : Media Abadi.

Rahmawati. 2007. Sastra Lisan Tolaki. Kendari: Kantor Bahasa Sulawesi Tenggara.

Soekanto, Soejono dan Ratih Lestarini. 1988. Fungsionalisme dan Teori Konflik Dalam Perkembangan Sosiologi. Jakarta: Sinar Grafika.

Soekanto, Soejono dan Talcott Parson. 1986. Fungsionalisme Imperatif. Jakarta: Rajawali.

Suwardi Endraswara. 2003. Metodologi Penelitian Budaya. Yogyakarta: Gadjah Mada University Press. 
Tarimana, Abdurrauf. 1993. Seri Etnografi: Kebudayaan Tolaki. Jakarta: Balai Pustaka.

TO. Ihromi (Ed). 1996. Pokok-Pokok Antropologi Budaya. Jakarta: Yayasan Obor Indonesia.

Taridala, Yusran. 2005. Perubahan Sosial Pada Masyarakat Tolaki (Sketsa AntropoSosial di Ranah Budaya Tolaki. Kendari: Yayasan Hijau Sejahtera. 